Structure and Origin of

the Koae Fault System,

Kilauea Volcano, Hawaii

G E O L O G I C A L S U R V E Y P R O FE S S I O NA L P A P E R 856 

STRUCTURE AND ORIGIN OF

THE KOAE FAULT SYSTEM, KILAUEA VOLCANO, HAWAII 


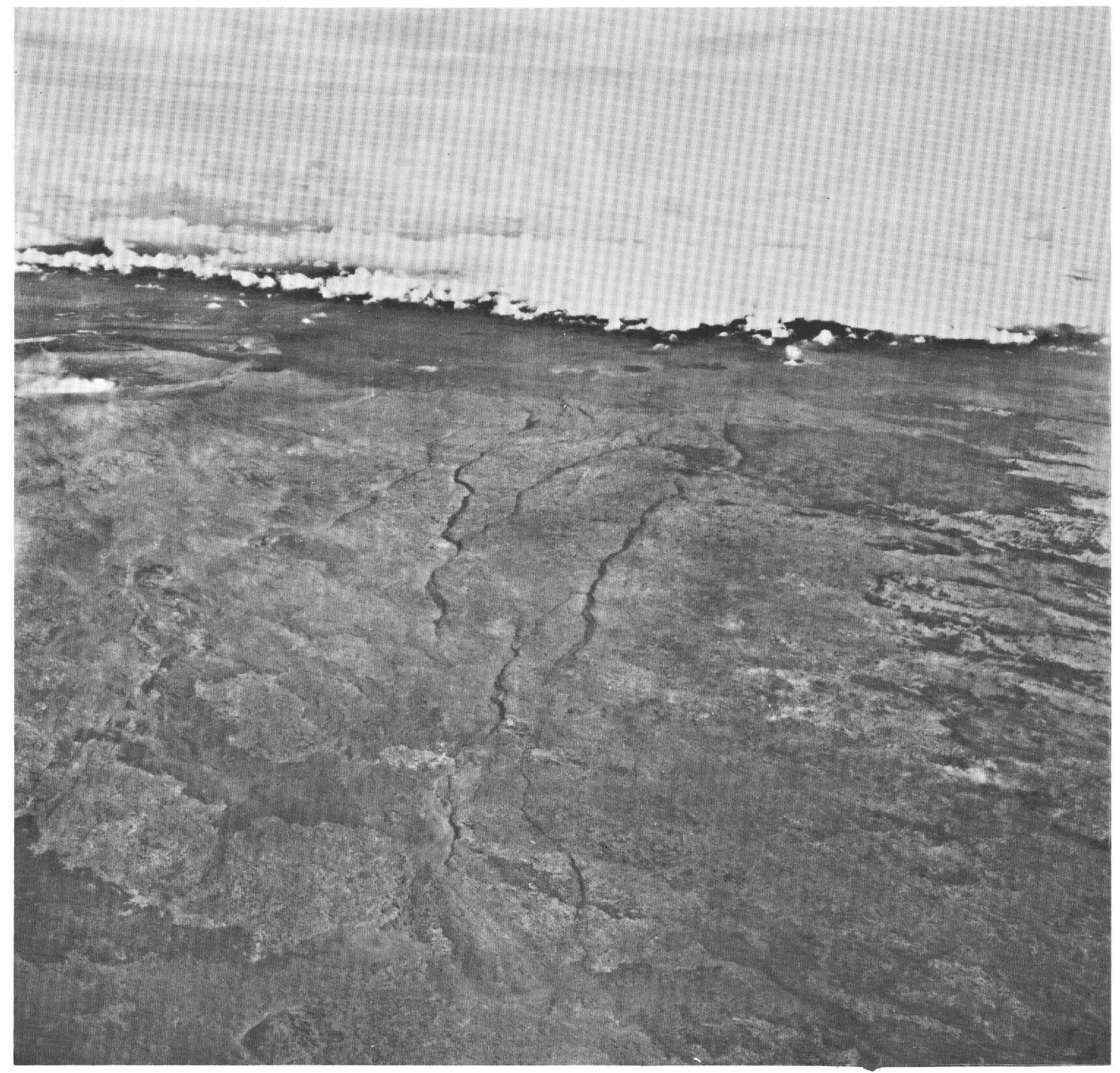

Oblique view to the east-northeast of the Koae fault system. Fume from Halemaumau pit crater on the floor of Kilauea caldera is visible in the upper left. Some cracks of the southwest rift zone can be seen along the left edge, and pit craters of the east rift zone indent the volcano in the middle distance. Note that the Koae fault zones are sinuous and that most scarps face north (to the left). 
Structure and Origin of the Koae Fault System, Kilauea Volcano, Hawaii By WENDELL A. DUFFIELD

GE OLOGICA L S URVEY PROFESSIONAL PAPER 856

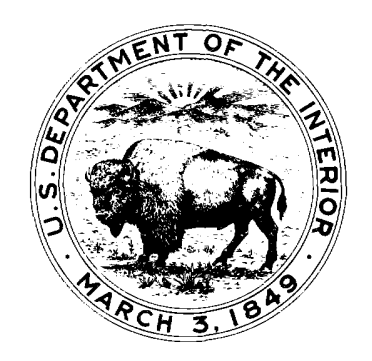




\section{UNITED STATES DEPARTMENT OF THE INTERIOR}

ROGERS C. B. MORTON, Secretary

GEOLOGICAL SURVEY

V. E. McKelvey, Director

Library of Congress Cataloging in Publication Data

Duffield, Wendell A.

Structure and origin of the Koae fault system, Kilauea Volcano, Hawaii.

(Geological Survey Professional Paper 856)

Bibliography: p. 12.

Supt. of Docs. No.: I 19.16:856

1. Faults (Geology)-Hawaii--Kilauea. I. Title. II. Series: United States. Geological Survey. Professional Paper 856. QE606.5.U6D83 $551.8^{\prime} 7$ 74-26895

For sale by the Superintendent of Documents, U.S. Government Printing Office Washington, D.C. 20402

Stock Number 024-001-02612 


\section{CONTENTS}

$\begin{array}{lll} & \\ \text { Abstract } & & \\ \text { Introduction } & 1 & \text { Origin } \\ \text { Acknowledgments } & 1 & \text { Depth of faulting } \\ \text { Method of study } & 2 & \text { Anomalous areas } \\ \text { General geology } & 2 & \text { Conclusions } \\ \text { Structural geology } & 2 & \text { Added note } \\ \text { Development of fault zones } & 4 & \text { References cited }\end{array}$

\section{ILLUSTRATIONS}

Frontispiece. Photograph of oblique view of the Koae fault system, looking east-northeast.

PLATE 1. Structural map of the central part of the Koae fault system

In pocket

Figure 1. Index map of Kilauea Volcano 1

2. Map of the principal normal fault zones of the Koae fault system

3. Histograms summarizing the trend of fissures and the direction of dilation

4. Photographs showing Koae fault zones in successive stages of development

5. Sketch of asymmetrical graben in tabular clay model

6. Graph of direction of dilation versus trend of fissure for the anomalous area of arcuate-concentric cracks

7. Sketch illustrating possible origin of observed dilation directions for fissures of the arcuate-concentric anomalous area

8. Map showing the eruptive fissures, lava flows, and zone of ground cracking of the May 5, 1973, eruption 



\title{
STRUCTURE AND ORIGIN OF THE KOAE FAULT SYSTEM, KILAUEA VOLCANO, HAWAII
}

\author{
By Wendell A. Duffield
}

ABSTRACT

The Koae fault system forms part of a continuous fault zone boundary that separates the south flank from the rest of Kilauea Volcano; the east and southwest rift zones form the rest of the boundary. The Koae system is about $12 \mathrm{~km}$ long by $2 \mathrm{~km}$ wide and is characterized by gaping cracks and long, sinuous normal fault zones with north-facing scarps. Most fractures are $200 \mathrm{~m}$ long or shorter and generally are arranged en echelon. With few exceptions, fractures dip vertically, strike $\mathrm{N} .75^{\circ} \mathrm{E}$., and have been dilated in a N. $15^{\circ} \mathrm{W} .-\mathrm{S} .15^{\circ} \mathrm{E}$ direction. Average dilation across the entire fault system is about 25 $\mathrm{m}$ and generally increases eastward along the Koae.

Both the trend of the Koae and the direction of dilation virtually parallel those of the lower east rift zone. Recent geodetic studies by D. A. Swanson, W. A. Duffield, and R. S. Fiske (unpub. data, 1973) indicate that the dilation results from the $\mathrm{S} .15^{\circ} \mathrm{E}$. displacement of the south flank, which in turn is caused by the forceful injection of dikes into the rifts-mostly the east rift. Thus the Koae is believed to represent a tear-away zone as the south flank is pushed southward by dike injection into the rifts. This process has almost certainly been active throughout the history of the Koae and probably will continue as long as Kilauea remains an active volcano.

\section{INTRODUCTION}

Kilauea is an active basaltic shield volcano on the island of Hawaii. The principal structural features that disrupt the shield are a summit caldera, the east and southwest rift zones, and the Koae and Hilina fault systems (fig. 1). Past detailed study of these features has involved mainly the summit area and the rift zones where eruptions are localized. Recently, however, the structures of parts of the volcano far from the sites of eruption have been studied in detail to learn how these more distant areas respond to magmatic processes. These recent structural studies focus on the south flank (Swanson and others, 1971; D. A. Swanson, W. A. Duffield, and R. S. Fiske, unpub. data, 1973) and the Koae fault system, the subject of this paper.

The Koae fault system traverses the upper slope of Kilauea's flank in an east-northeast direction south of the summit caldera (fig. 1). The zone of faulting is about $12 \mathrm{~km}$ long and tapers westward from 3 to $1 \mathrm{~km}$ wide. The north-central part of the zone is poorly defined where it overlaps an area with fractures related to the south part of the summit caldera, but the south boundary is clearly marked by a high north-facing fault scarp.
The Koae merges at its two ends with the southwest and east rifts, and together these three structural features form a continuous fault zone of extension that separates the structural block of the south flank from the rest of the volcano. Geodetic and seismic studies by D. A. Swanson, W. A. Duffield, and R. S. Fiske (unpub. data, 1973) and Koyanagi, Swanson, and Endo (1972) suggest that the fault zone of extension may penetrate the shield edifice to a depth of about $10 \mathrm{~km}$, the approximate level of the ocean floor, thereby detaching the south flank from the rest of the volcano. Thus, the Koae fault system is part of a major structural zone of much importance in understanding the volcano.

Unlike the two rift zones, the Koae fault system has rarely been the site of recognizable eruptions, and then only in areas of overlap with the rifts; consequently, structures in the Koae have not been quickly buried by new lava flows as have similar structures in the rift

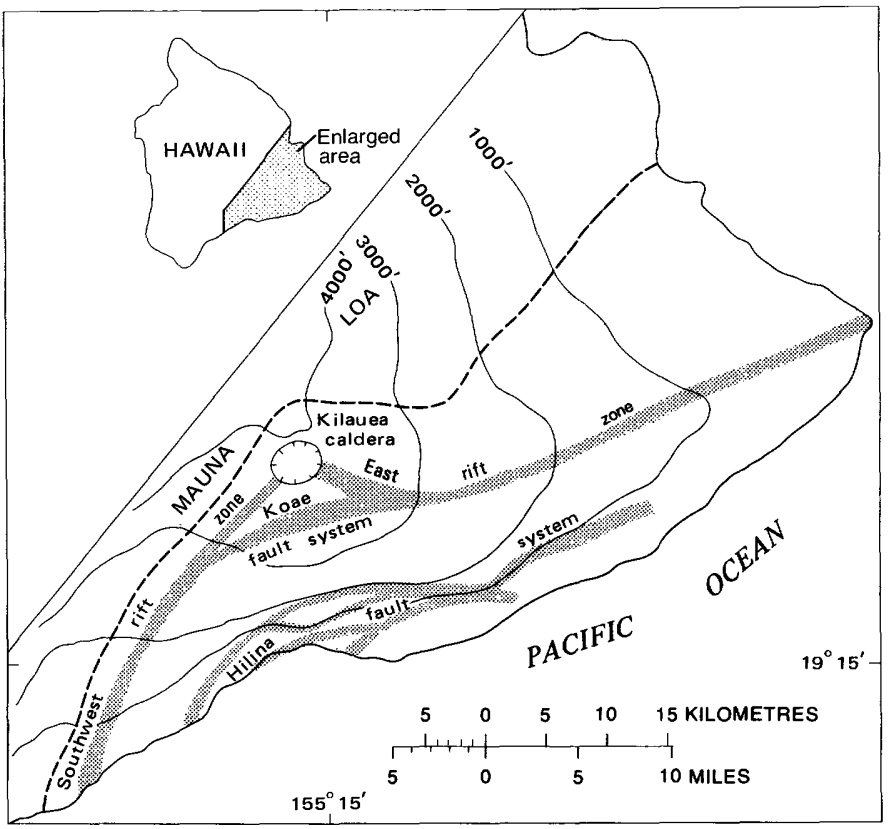

Figure 1.-Index map of Kilauea Volcano. The broken line marks the approximate contact between Mauna Loa and Kilauea lavas. Contour interval is 1,000 feet. 
zones. Thus the Koae provides the best opportunity to study part of the fault boundary of the south flank. Furthermore, Koae structures are so young and well preserved that faulted flows generally can be reconstructed to provide accurate measurements of net relative ground displacement across the faults. Geodetic data for closely observed historic faulting have provided accurate displacement information for individual events. For example, some vertical displacements within the Koae fault system were accurately measured by precise leveling relative to distant undisturbed stations after an episode of major faulting in 1965 (Fiske and Koyanagi, 1968). With the present geodetic networks at Kilauea, both vertical and horizontal displacements within the Koae can be measured relative to stable areas. Such information will provide valuable insight into the past as well as the present behavior of the fault system. This paper focuses principally on comparing structures produced by older faulting with those produced during the most recent events in an attempt to formulate a generally applicable mode of origin for the entire fault system.

\section{ACKNOWLEDGMENTS}

Many workers over the years have contributed data and ideas toward a better understanding of the Koae fault system. I have drawn heavily on these earlier efforts and am especially indebted to Richard S. Fiske, Willie T. Kinoshita, Robert Y. Koyanagi, Donald A. Swanson, George W. Walker, and Peter L. Ward. I also thank Donald A. Swanson and Carroll A. Hodges for helpful reviews of the manuscript.

\section{METHOD OF STUDY}

Detailed structural mapping was the main method of study. The central part of the fault system was examined carefully in the field. Field data were plotted on orthophotographs of 1:4,800 scale and subsequently reduced to a publication scale of $1: 7,500$ (pl. 1). Virtually all individual cracks and faults could be resolved on the orthophotographs, providing as complete a structural map as reasonably possible. Vertical fault scarps as high as about $4 \mathrm{~m}$ were measured to the nearest one-half metre with a steel tape; however, the heights of the higher scarps were visually estimated, and the highest estimates (about $20 \mathrm{~m}$ ) may be in error as much as 2-3 $\mathrm{m}$. Azimuths and amounts of horizontal opening were measured with a Brunton compass and steel tape.

Parts of the east and west ends of the fault system were examined briefly in the field but were mapped (fig. 2) almost completely by study and interpretation of aerial photographs. All available data indicate that generalizations drawn from the detailed study of the central Koae are valid for the entire fault system.

\section{GENERAL GEOLOGY}

Most of the area is underlain by pahoehoe flows that dip gently southward. These have been called "regional pahoehoe flows" by Walker (1969). The flows are as much as $10 \mathrm{~m}$ thick locally, but most average just 1 or 2 $\mathrm{m}$. Steeply plunging pipe vesicles are abundant locally, both near the margins and in the interiors of flows, and a few percent by volume of small nearly spheroidal vesicles is common. In general, however, the flows are quite dense. The pahoehoe is characterized by a very hummocky surface and is of the type that formed from relatively degassed lava after long flowage through tubes during the 1969-71 eruption of Kilauea at Mauna Ulu (Swanson, 1973). Many successive flows of this same type of pahoehoe are exposed in the Koae fault scarps.

A few small patches of aa crop out in the area; most appear to have issued from tubes, as did the pahoehoe. All the pahoehoe flows are jointed into irregularly developed columns. Tectonic cracks and faults partly follow these joints, resulting in highly serrate fault-block boundaries that are easily matched across the breaks.

\section{STRUCTURAL GEOLOGY}

The principal structures of the Koae fault system are steeply dipping north-northeast-trending open cracks and normal faults having a component of dilation. Some of the faults and cracks have opened as much as 1-2 m, and vertical offsets are as much as $20 \mathrm{~m}$. All dips are vertical within the errors of measurement. Locally, facing fault scarps form symmetrical structural and topographic grabens, as at the east end of the fault system; most scarps, however, face northward, imparting a pronounced transverse asymmetry to the zone (fig. 2 ; frontispiece).

Individual fractures generally are linear, $200 \mathrm{~m}$ long or shorter, and commonly are concentrated in sinuous zones as much as $12 \mathrm{~km}$ long (fig. 2). In a crude way, the fractures may be grouped into four such zones, spaced about $700 \mathrm{~m}$ apart (fig. 2); between the fracture zones, especially in the western Koae, the rocks generally are not tectonically broken, and thus vertical offset there is minor. (See pl. 1, west of $A-A^{\prime}$.)

Faults and cracks are characteristically arranged en echelon in zones whose trends locally diverge greatly from those of individual fissures and the fault system itself (pl. 1). Several good examples of such divergence can be seen along traverse $A-A^{\prime}$ (pl. 1). Earlier generalized geologic maps, such as that of Walker (1969), do not show this clearly, for only at much larger scales can the distinction between individual fractures and zones of fractures be shown. All the major zones of faulting are in fact sinuous in plan view (fig. 2; pl. 1), and close field examination reveals that this pattern 


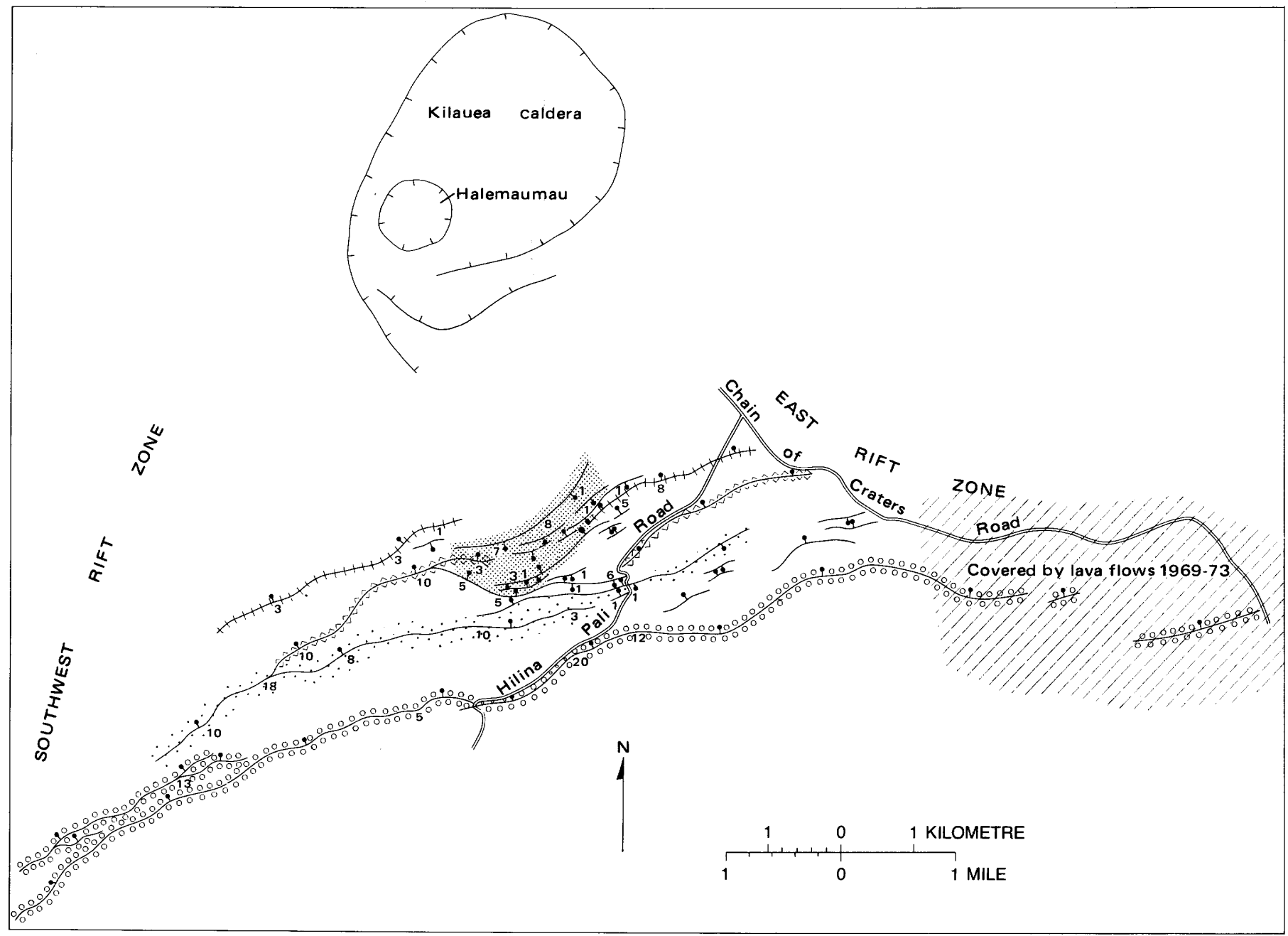

FIGURE 2.-Principal normal fault zones of the Koae fault system. The four main zones are patterned (see text). Vertical offset is in metres. Note that most of the scarps face to the north. The ratio of the outcrop length of north-facing to south-facing scarps is about 5:1 (19:1 if an area of anomalous arcuate-concentric fissures in the north-central Koae (shaded area) is disregarded).

results from the arrangement of sets of dextral and sinistral en echelon fractures on opposing limbs of arcuate zones. Good examples of such a fracture pattern can be seen about 1,400 m northwest of Ohale, near the 3,327 spot elevation, and at several locations along Kalanaokuaiki Pali, east of $A^{\prime}$ (pl. 1). Field recognition of this pattern is easy in zones with little or no vertical offset; recognition becomes increasingly difficult with greater normal faulting because the evidence for en echelon faulting is largely destroyed by a single large curved master fracture that eventually forms along the axial part of a fault zone. Nonetheless, careful examination at the base and top of even the highest fault scarps generally reveals the ends of the en echelon fractures.

The direction and amount of horizontal offset across cracks and faults are readily determined because walls of most fissures can be almost perfectly matched like pieces of a jigsaw puzzle. The directional data of many such measurements, paired with the trend of each measured fissure, are summarized as histograms in figure 3 . The field locations of these measurements are distributed rather evenly throughout the area mapped in detail (pl. 1) with regard to approximate total surface length of fracturing per unit area. Most measured fissures showed little or no vertical offset and ranged from 4 to $170 \mathrm{~cm}$ of horizontal opening, averaging about $50 \mathrm{~cm}$; flows broken by fractures with considerable vertical offset generally are difficult to reconstruct accurately, and hairline tectonic breaks are often easily confused with cooling joints.

All field measurements are subject to some error, mostly caused by slight nonlinearity of fissures and by minor difficulties in measuring the precise direction of opening on gaping cracks. It is estimated that $\pm 5^{\circ}$ is a generously large margin of error for these uncertainties. Bearing this in mind, the histograms of figure 3 show that most fissures trend between N. $66^{\circ}$ E. and $76^{\circ}$ E., generally parallel to the Koae fault system itself. 


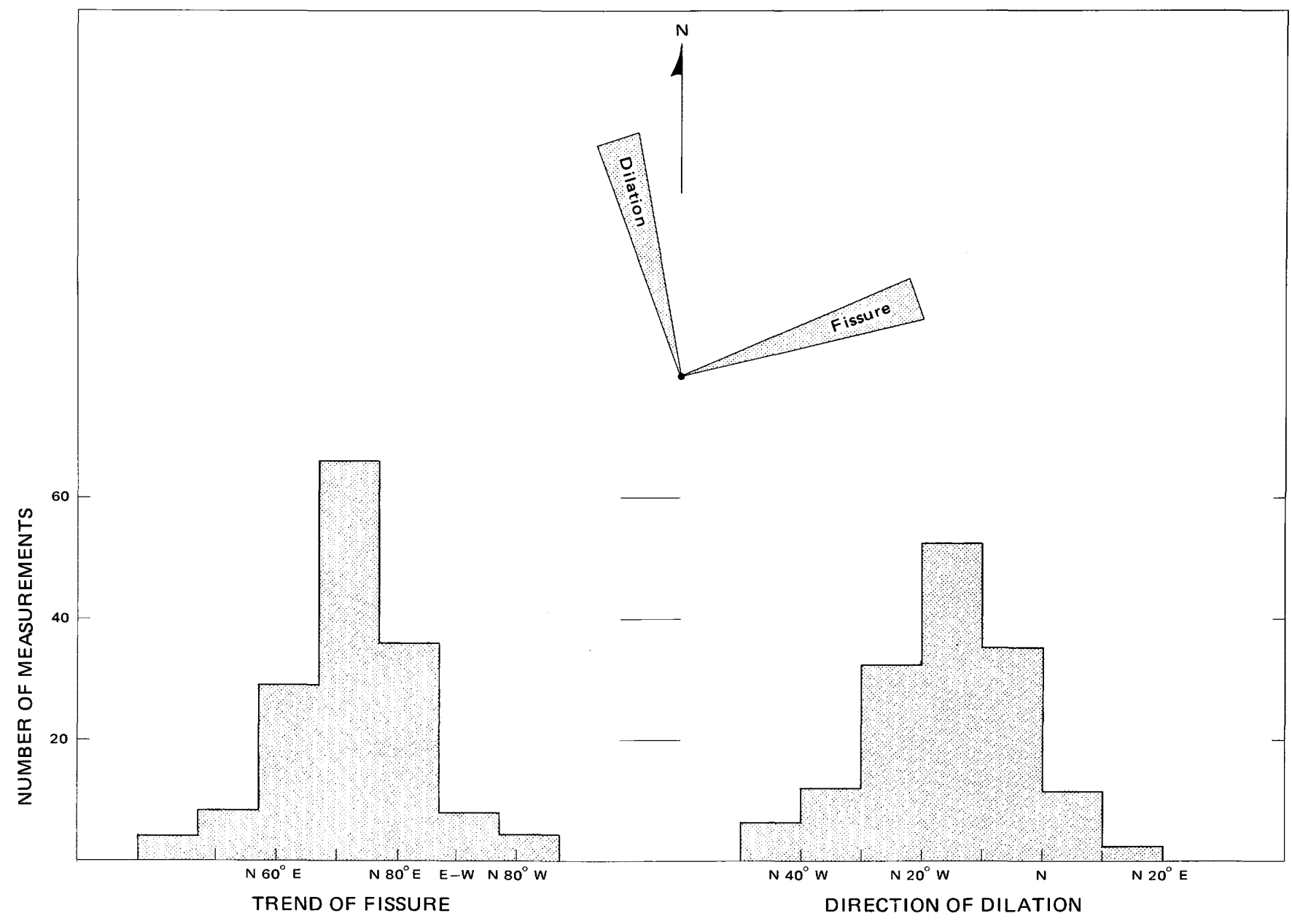

FIGURE 3.-Histograms summarizing the trend of fissures and the direction of dilation. The rose diagram shows only the preferred directions, to emphasize the perpendicular relation. Within the errors of measurement, the two directions are perpendicular. Data from an anomalous area of arcuate-concentric fissures (see text) are not included here.

This parallelism is consistent with the earlier observation that the sinuousity of fault zones results from the en echelon arrangement of relatively short parallel fractures, not long curvilinear breaks. Within the errors of measurement, the direction of dilation is perpendicular to the preferred trend of fissures, that is, about N. $10^{\circ} \mathrm{W}$. to $\mathrm{N} .20^{\circ} \mathrm{W}$. (fig. 3). A similar direction of dilation also has been determined indirectly from a study of the trends of zones of en echelon fractures (Duffield and Nakamura, 1973).

The total amount of dilation across the fault system was measured with a steel tape along two traverses (pl. $\left.1, A-A^{\prime}, B-B^{\prime}\right)$. The western line shows $18.69 \mathrm{~m}$ of opening, and the eastern line $32.55 \mathrm{~m}$. The eastern line was measured independently by another worker, who found $33 \mathrm{~m}$ of opening, virtually identical to the results of this study. The greater amount of opening along the eastern profile is believed to reflect the proximity of the principal source of dilation, as explained in the discussion of the origin of the fault system.
Vertical fault offsets as represented by the heights of fault scarps are beautifully preserved and easily measured. Selected measurements are summarized on plate 1 and in figure 2 . In the strict sense, the height of a scarp represents a minimum value of total vertical displacement. However, the faults are so young that they are virtually unaltered by erosion, and for nearly all the Koae there is no good evidence of postfaulting lava flows ponded at the base of scarps; consequently, except for local pockets of wind- and water-borne sand at the base of some, nearly all the presently exposed scarps effectively reflect total vertical offset.

\section{DEVELOPMENT OF FAULT ZONES}

Close field examination suggests that the Koae fault zones represent the culmination of multiple tectonic episodes that are characterized by horizontal dilation and concomitant vertical ground displacement. Fault zones in various stages of development are present, and those pictured in figure 4 are believed to represent four 

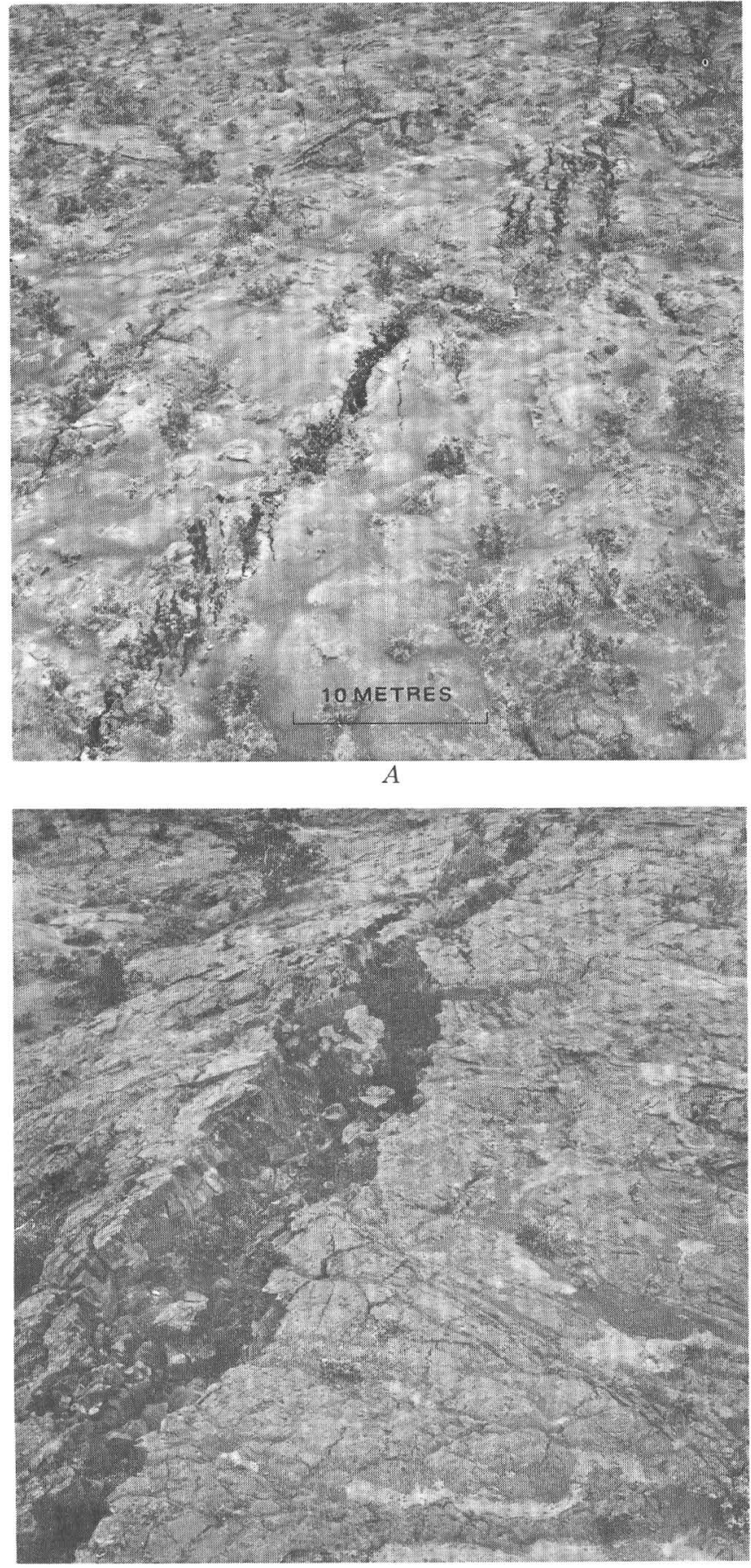

$B$

Figure 4.-Koae fault zones in successive stages of development. $A$, Initial stage: Zone of en echelon fractures with no vertical offset. Dilation is oriented toward the sides of the photograph, perpendicular to the trend of the individual fractures. $B$, Intermediate stage: North is to the left. A broken monoclinal flexure has formed. Most of the initial en echelon breaks have joined along a master fracture located here beneath the rubble-strewn cleft. Note the broken ramp bounded by two original en echelon breaks and spanning the pro-

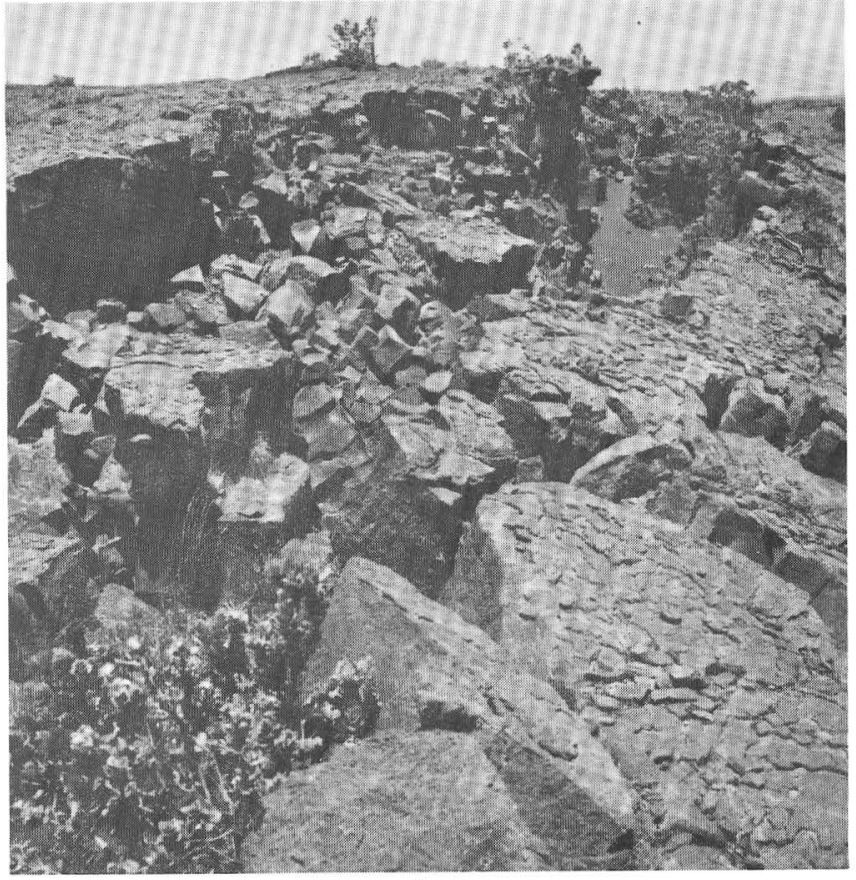

C

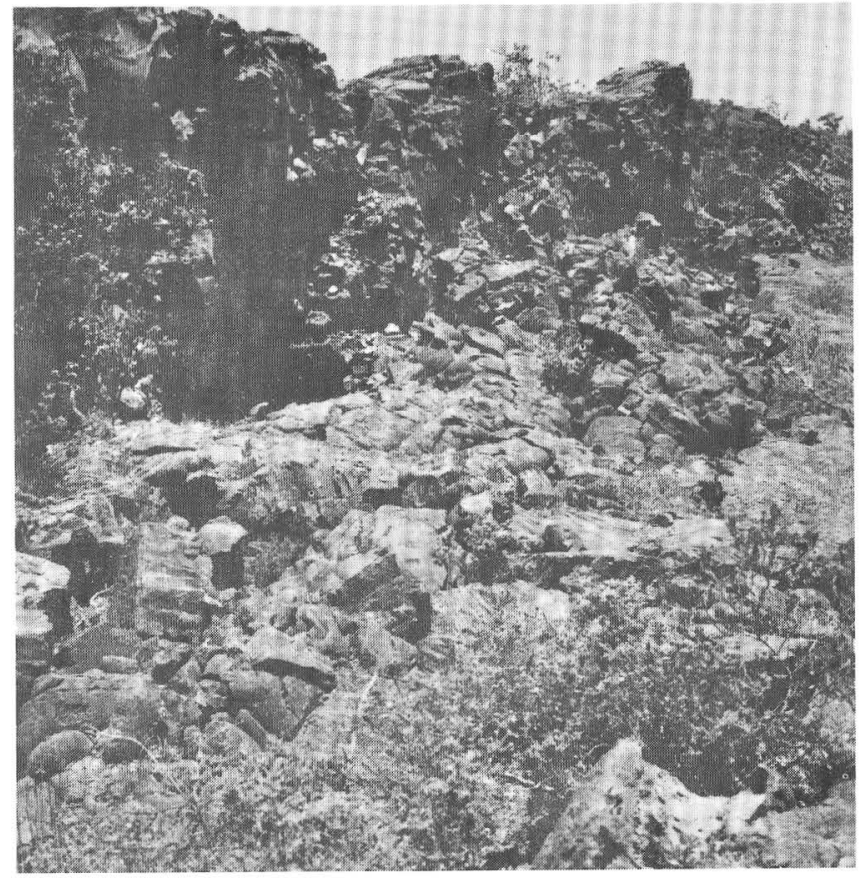

$D$

jected trace of the master fracture in the center of the photograph. $C$, Intermediate stage: North is to the right. Similar to $B$ except that vertical offset is now prominent along the master fracture. Note the broken but still recognizable ramp near the center of the view. $D$, Advanced stage: North is to the right. Vertical offset is about $8 \mathrm{~m}$. View is along the trend of the initial en echelon fractures. Note the irregularities (ribbing) of the scarp where these original fractures and the scarp intersect. The en echelon fractures are also recognizable in the downdropped block, near foreground. 
successive stages, from initial formation of tectonic fissures to formation of a lofty normal fault scarp. The principal events are as follows: (1) A zone of fractures several metres wide initially forms in response to horizontal dilation (fig. $4 A$ ). Individual fractures dip steeply and are parallel, or nearly so. The zone may be linear but generally is sinuous because of sets of dextral and sinistral en echelon fractures. (2) As horizontal dilation increases, the northern block is relatively downdropped, warping the flows into a broken irregular monoclinal flexure (Macdonald, 1957); individual fractures grow longer and open wider, increasing the width of the zone, and many of the en echelon fractures join to produce a wide crack (fig. $4 B$ ). (3) With still further dilation and vertical offset, the gaping en echelon fractures join to form a single continuous master fault along the axial part of the zone, bordered by a north-facing fault scarp that is slightly ribbed where it intersects the original en echelon fractures (fig. $4 C, D$ ). Before the master fault is completely developed, tilted slabs (part of the earlier monocline), bounded by the initial en echelon fractures, form ramps between the two fault blocks (fig. $4 B, C$ ). Any additional dilation generally destroys such ramps, which fall into the gaping master fault, and causes increased vertical offset and more opening along the fault trace, commonly with some rotation of the downthrown block into the fault zone. At this stage of development, the zone of fractures is as much as $40 \mathrm{~m}$ wide. Minor complications are common in the fault zone and are mostly related to the early monoclinal warping and to irregular protrusions on the fault blocks that catch on one another during vertical offset.

In the advanced stage of fault development, a zone of fractures parallel to the master fault often forms in the downthrown block as it slumps and rotates forward into the gaping space along the master break. This type of secondary effect is widespread but perhaps best developed locally along the southernmost fault zone in the southeast part of plate 1 . Though such slump blocks most often rotate forward into the fault zone, they also may drop vertically to form a small graben from a few to tens of metres wide.

The foregoing sequence of events seems reasonable, solely on the basis of characteristics of the fault zones, but details of actual ground displacement during the growth of the zones are less easily explained. After an episode of faulting in 1965, precise leveling surveys showed that for the most southerly of the Koae fault zone, the lower (north) block dropped about $1 \mathrm{~m}$ relative to distant virtually undisturbed stations, while the upper (south) block rose about $3 \mathrm{~m}$ (Fiske and Koyanagi, 1968). This substantial uplift has been tentatively explained as an elastic rebound effect (Fiske and Koyanagi, 1968). It may also be explained as uplift of the south flank that is related to diking in the rift zones (D. A. Swanson, W. A. Duffield, and R. F. Fiske, unpub. data, 1973).

Great southward tilting accompanied this 1965 uplift (Fiske and Koyanagi, 1968). Topographic profiles across the Koae suggest the possibility of similar tilting of other Koae fault blocks in the past because these blocks generally project well above the present summit elevation. However, such profiles must be interpreted with caution because of primary irregularities on flow surfaces and southward increase in surface slope on a shield volcano such as Kilauea. Hopefully, precise measurement of ground displacement for future Koae faulting events will clarify the nature of offsets. Data discussed in the following section suggest a single preferred direction of horizontal ground displacement relative to virtually undisturbed stations, but in the interim, vertical offsets as seen in the normal fault scarps can be described only as relative displacements across the faults themselves.

\section{ORIGIN}

The origin of the Koae fault system is believed to be closely related to intrusion of magma into the two rifts, principally the east rift, and can be understood only after close examination of such intrusions and related ground deformation and seismicity. Many conclusions from detailed studies of this sort are summarized subsequently (Swanson and others, 1971; D. A. Swanson, W. A. Duffield, and R. S. Fiske, unpub. data, 1973; Koyanagi and others, 1972).

The potential for renewed Koae dilation and faulting occurs whenever magma is forcefully injected into the rift zones as steeply dipping dikes. The initial depth of intrusion is poorly known, but seismic evidence suggests $2-5 \mathrm{~km}$ (Koyanagi and others, 1972). Some dikes reach the surface and feed eruptions. Seismic evidence also suggests that some may propagate downward, for some hypocenters associated with diking are as deep as $10 \mathrm{~km}$ beneath the rift (Koyanagi and others, 1972). Dike injection forcibly dilates the rift zone, displacing wallrock directly away from the fissure, and in this manner virtually all of the south flank is pushed southward (Swanson and others, 1971). Since about 1900, net displacements have averaged $2-3 \mathrm{~m}$, with maximum southward displacement of at least $4.5 \mathrm{~m}$ directly opposite the most active part of the east rift (D. A. Swanson, W. A. Duffield, and R. S. Fiske, unpub. data, 1973).

The Koae fault system is believed to be a tear-away zone related to this process of southward displacement of the south flank. With continued diking in the rifts, stresses generated there migrate into the Koae, eventually causing faulting. Thus, the fault system grows by repeated episodes of injection of magma into the rifts, tearing the volcano apart as the south flank is forced 
away from the rifts. Koae fractures remain exposed because eruptions generally do not occur there and lava flows seldom enter the area, whereas similar fractures in the rift zones tend to be quickly filled and covered by younger flows.

Several lines of evidence indicate that the east rift has dominated the wedging process and development of the Koae fault system. For example, frequent eruptions from the east rift have built a huge tapering bulge on the flank of Kilauea, whereas the southwest rift barely disturbs the normal gradient of the shield (Stearns and Macdonald, 1946, pl. 1). Clearly much more lava has erupted from the east rift than the southwest, presumably with more attendant dike-induced dilation. Furthermore, both the width of the fault system and total dilation decrease westward, probably correlating with increased distance from the principal source of dilation. Finally, and perhaps most importantly, the direction of dilation across the Koae parallels that across the east rift and the direction of horizontal displacement of the entire fault-bounded south flank (D. A. Swanson, W. A. Duffield, and R. S. Fiske, unpub. data, 1973) but is oblique to normal dilation of the southwest rift zone. A trilateration survey after a recent eruption (Sept. 1971) from the southwest rift indicated seaward motion of the south flank, directly away from that rift, in accordance with the general model proposed earlier. But the southwest rift has been relatively inactive, and the parallel directions of Koae and east-rift dilations and 20 th century displacement of the south flank argue strongly for nearly total dominance of the east rift in forming the Koae fault system.

The studies by D. A. Swanson, W. A. Duffield, and R. S. Fiske (unpub. data, 1973) have shown that dilation of the east rift probably is almost completely accommodated by seaward (southward) displacement of the south flank. The edifice north of the rift remains virtually stationary, presumably because it is buttressed by neighboring Mauna Loa volcano, whereas the block to the south is unbuttressed and relatively free to move. Similarly, dilation of the Koae fault system is probably southward directed since it results from a S. $20^{\circ} \mathrm{E}$. displacement of the adjacent part of the south flank.

Closer examination indicates that this proposed manner of growth is somewhat oversimplified. For example, shallow intrusion of magma beneath the summit caldera just north of the central Koae in May 1970 caused some closing of Koae cracks and faults (W. A. Duffield, D. A. Swanson, and D. B. Jackson, unpub. data, 1973). The Koae undoubtedly responds to other structural events in the summit area and should be thought of as undergoing an accordionlike deformation, but with by far the greatest source of movement resulting from southward displacement of the south flank.
Any proposed origin of the Koae fault system must explain why nearly all the fault scarps face northward. Some clay modeling experiments by Cloos (1968) provide a possible explanation and support the idea of growth through southward displacement of the south flank. Cloos produced grabens in tabular clay models by horizontal dilation transmitted to the clay through underlying movable templates. When two abutting templates were pulled apart, a symmetric graben formed normal to the direction of pull. However, when two overlapping templates were pulled apart, a structure termed an asymmetric graben by Cloose was produced (fig. 5). The asymmetric graben is characterized by a single major normal fault, and in the experiment that is believed to be analogous to the Koae, this fault faces away from the direction of pull (Cloos, 1968, fig. 18). The downthrown block deforms by warping, cracking, and slumping to fill the void produced by dilation.

At the surface, the asymmetric graben of Cloos's experiments is a remarkably similar miniature version of virtually any of the north-facing fault zones in the Koae fault system. A truly scaled equivalence between the field situation and the clay model is lacking, but the similarity suggests more than a chance likeness. If the two situations are indeed analogous in three dimensions, fractures of the Koae must terminate on some

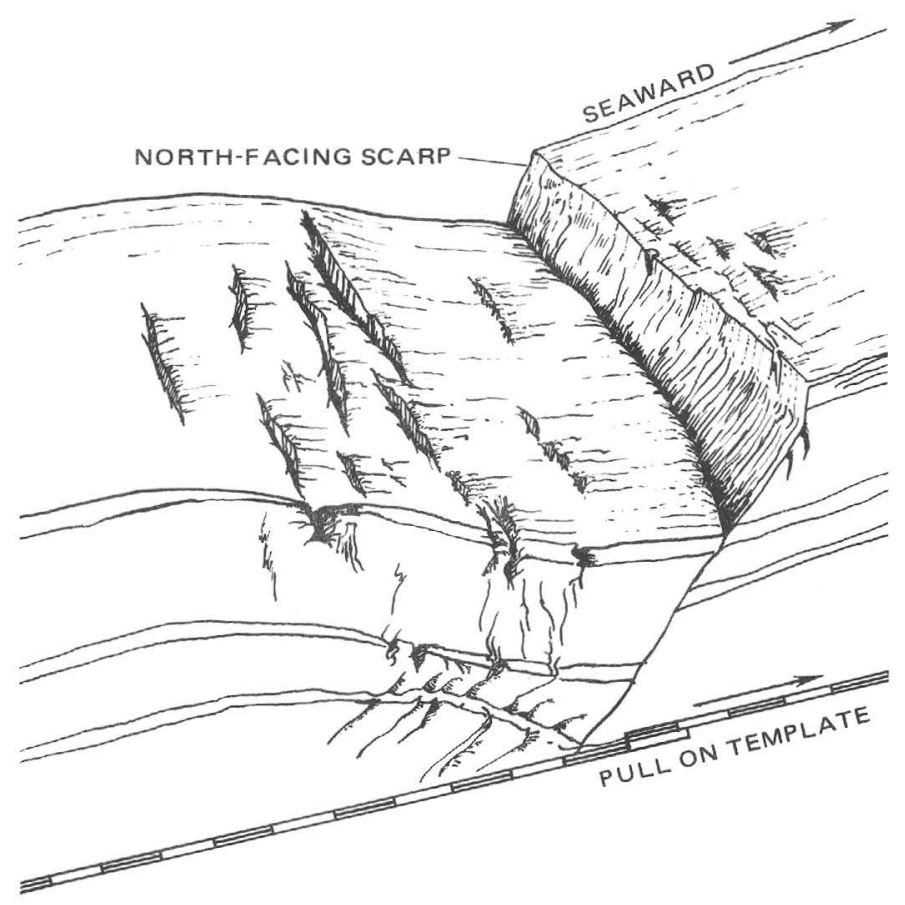

Figure 5.-Asymmetric graben in tabular clay model (after Cloos, 1968, fig. 18). The fault zone produced in this experiment is a remarkably similar miniature version of a Koae fault zone. Note that the scarp faces away from the direction of pull on the template, just as typical Koae fault scarps face northward in response to southward displacement of Kilauea's south flank. 
horizontal surface of slippage. The distribution of earthquake hypocenters associated with rift diking suggests one such plane at the base of the mobile south flank, about $10 \mathrm{~km}$ deep. Another nearly horizontal surface of possible slippage occurs at about $1 \mathrm{~km}$ in depth, where a layer of relatively weak hyaloclastite is believed to exist (Moore and Fiske, 1969). Possibly, differential slippage on horizontal surfaces occurs at more than one level.

\section{DEPTH OF FAULTING}

If the origin of Koae faulting proposed here is valid, the faults should penetrate about as deeply as the dikes that ultimately cause them. Seismic evidence suggests a maximum depth of about $10 \mathrm{~km}$ - at or near the base of the volcano. Application of the graben rule of Hansen (1965), however, predicts a much shallower depth. The graben rule is a statement of conservation of volume (or, alternatively, cross-sectional area) applied to the formation of a graben by dilation on a translatory fault. The cross-sectional area of the graben is considered equal to that created by dilation of the fault through the expression $D=A / l$, where $D$ is the depth of faulting, $l$ is the horizontal dilation of the fault, and $A$ is the crosssectional area of the graben. Application of this relation to the central Koae, considering the entire fault zone to be one complex graben, indicates that $A$ is approximately $2 \times 10^{4} \mathrm{~m}^{2}$ (10 m average depth $\times 2 \mathrm{~km}$ width) and $l$ is $30 \mathrm{~m}$, for a calculated fault depth of $667 \mathrm{~m}$. This is clearly at odds with the 10-km depth suggested by seismic evidence.

Some of this discrepancy may be accounted for by the volume along gaping cracks, but this uncertainty in the calculation is small. All the discrepancy may be explained by the presence of dikes, largely filling Koae cracks to a relatively shallow depth. Some intrusion of dikes into the easternmost Koae is known (see following section), and an anomalously warm, sometimes steaming area in the north-central Koae suggests the shallow intrusion of magma there; in general, however, there is no surface indication of abundant diking in the Koae.

To explain the results of a detailed gravity survey of the area, W. T. Kinoshita (oral commun., 1973) has concluded that Koae faults are partly filled by relatively dense material (dikes). However, if Koae faults are partly filled by dikes, an additional dilemma arises: Why has none of these dikes wedged its way to the surface? A possible answer is that only relatively degassed magma is fed into Koae faults and thus the driving force for eruption is diminished. One could speculate further, but existing evidence is still too flimsy for any well-founded conclusion; whether diking is common in the Koae fault system or not remains unknown.

\section{ANOMALOUS AREAS}

Thus far the Koae has been characterized as a system of asymmetric grabens whose fault scarps face northward. Two relatively small areas, however, do not conform to this general pattern. A few grabens are symmetric; these are localized at the east end of the fault zone, where the Koae and east rift merge (fig. 2). Symmetric grabens are common in the east rift zone and are thought to be keystone grabens that form directly above a dike as it wedges its way toward the surface. Similarly, symmetric grabens of the easternmost Koae are believed to be localized there simply because dikes are emplaced in or very near the area. During May of 1969 and again in 1973, an erupting dike actually penetrated several hundred metres into the Koae-east rift area of overlap, and similar dike impingement into the easternmost Koae likely has occurred before.

Another anomalous area occurs in the north-central part of the fault system, almost directly south of Kilauea caldera (fig. 2; pl. 1). Unlike normal Koae fracture zones, here the zones are arcuate and concentric about a central area. The individual fractures, too, are generally concentric to this center rather than oriented N. $70^{\circ}$ E., as in the rest of the Koae. Most of the southfacing scarps of the Koae are localized here, and the only major south-facing fault scarp in the entire system forms the north boundary of the area. Furthermore, the density of tectonic fracturing, as measured by the strike length of fractures per unit area, is considerably greater than elsewhere in the Koae (pl. 1).

Measurements of fracture and dilation directions for the anomalous area (fig. 6) define a roughly linear distribution, and the slope of the best-fit straight line through them is about -1 , indicating that, to a first approximation, all fractures show perpendicular dilation. More refined analysis, however, indicates systematic departure from the simple linear interpretation. For cracks tending west-northwest (that is, the south-southwest sector of the arcuate structure), nearly all data points lie below the calculated best-fit line, indicating a nonperpendicular relation between crack and dilation directions there. Accurate dilation directions for the east sector of the structure (that is, where cracks trend more northerly than about N. $50^{\circ}$ E.) generally were impossible to measure because oblique opening has jumbled flows beyond accurate reconstruction there. The few data points gathered in this area (see the upper left corner of fig. 6) are probably in error $\pm 10^{\circ}-15^{\circ}$; in general, however, it is possible to reconstruct the jumbled flows well enough to see that the direction of oblique opening is between about N. $50^{\circ} \mathrm{W}$. and $\mathrm{N} .70^{\circ} \mathrm{W}$., that is, above line 1 of figure 6 . Therefore, an S-shaped curve such as line 2 of figure 6 best de- 


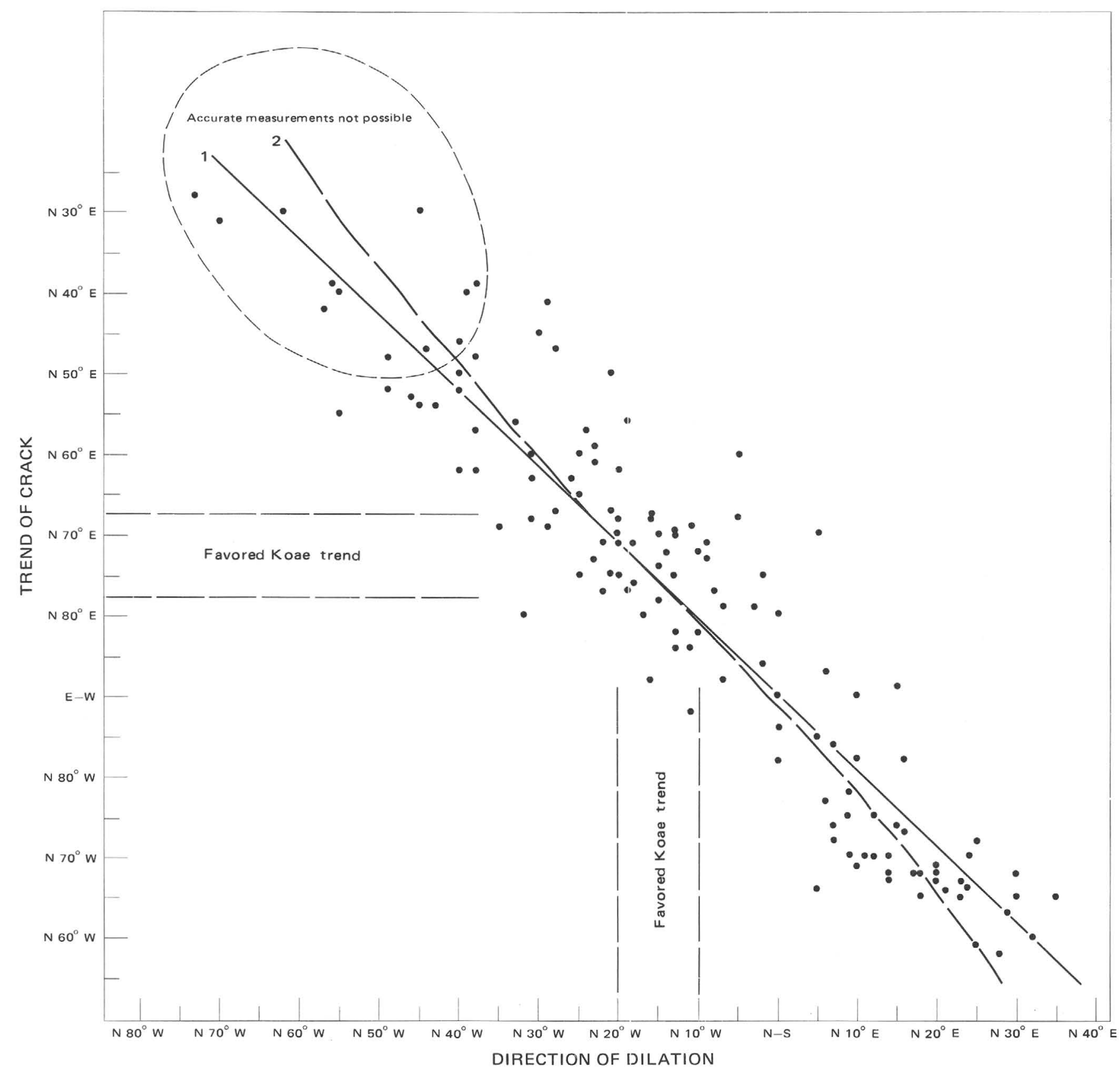

FIGURE 6. - Direction of dilation versus trend of fissure for the anomalous area of arcuate-concentric cracks. Line 1 is a least-squares linear best fit. Line 2 is a visual best fit. (See text for further explanation.)

scribes the entire anomalous structure and indicates dilation that is exactly perpendicular to individual fissures only at about N. $15^{\circ} \mathrm{W}$., the principal dilation direction elsewhere in the Koae fault system (compare with fig. 3). The two tails of the S-shaped curve reflect departures in opposite senses from this direction.

These departures can be explained as the net resultant of two superposed effects: (1) formation of arcuate fissures with perpendicular dilation and (2) subsequent dilation along the principal Koae trend dilation (fig. 7). The initial formation of fissures apparently resulted from a stress field with radial symmetry in the horizontal plane, perhaps caused by relatively shallow magma intrusion of crudely spherical or steeply plunging cylindrical shape and subsequent withdrawal. Once the fissures were formed, dike-induced Koae dilation, as proposed for the general origin of the fault system, caused further dilation in the principal Koae direction. 


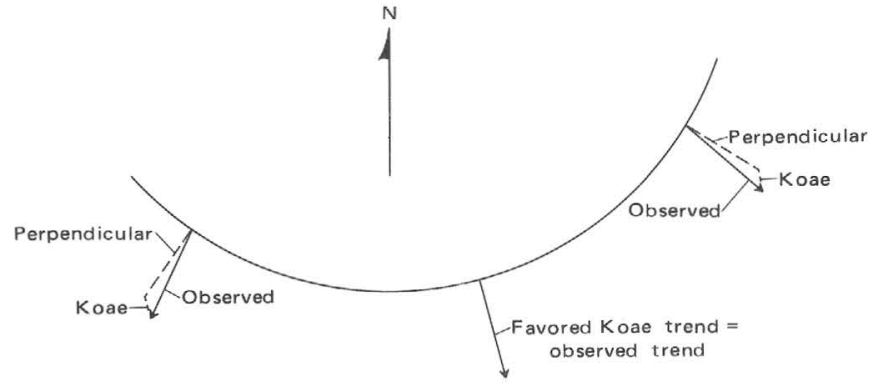

FIGURE 7.-Possible origin of observed dilation directions for fissures of the arcuate-concentric anomalous area. See text for discussion.

\section{AGE}

The Koae fault system is still active and presumably will remain so at least as long as Kilauea's rift zones are injected by dikes. The most recent major episode of faulting occurred in December 1965. New vertical offset of $4 \mathrm{~m}$ was measured across one fault zone, and myriads of newly formed and preexisting cracks were dilated (Fiske and Koyanagi, 1968). Other recent episodes of faulting occurred in December 1962 (Moore and Krivoy, 1964), May 1963 (Kinoshita, 1967) and July 1963 (Hawaiian Volcano Observatory, unpub. data, 1963).

Most or all of the Koae faults appear to have formed after the last widespread lava flow or flows that flooded the area because little evidence suggests ponding of lava at the base of north-facing scarps. A smooth surface texture on the flow where the Hilina Pali Road crosses Kalanaokuaiki Pali (pl. 1; fig. 2) is similar to that which develops on ponded lava, but this surface occurs on both fault blocks, suggesting local ponding before faulting.

The age of the youngest widespread flow(s) in the area can be estimated from the age of formation of the summit caldera. This procedure assumes that lava erupted from the summit area periodically buried Koae faults until formation of a caldera in which lava was ponded. Data on ash deposits presented by Powers (1948) suggest that the present caldera may have formed about 2,500 years ago, the ${ }^{14} \mathrm{C}$ age (Rubin and Suess, 1956) of organic debris from an ash bed on the east rim of the caldera.

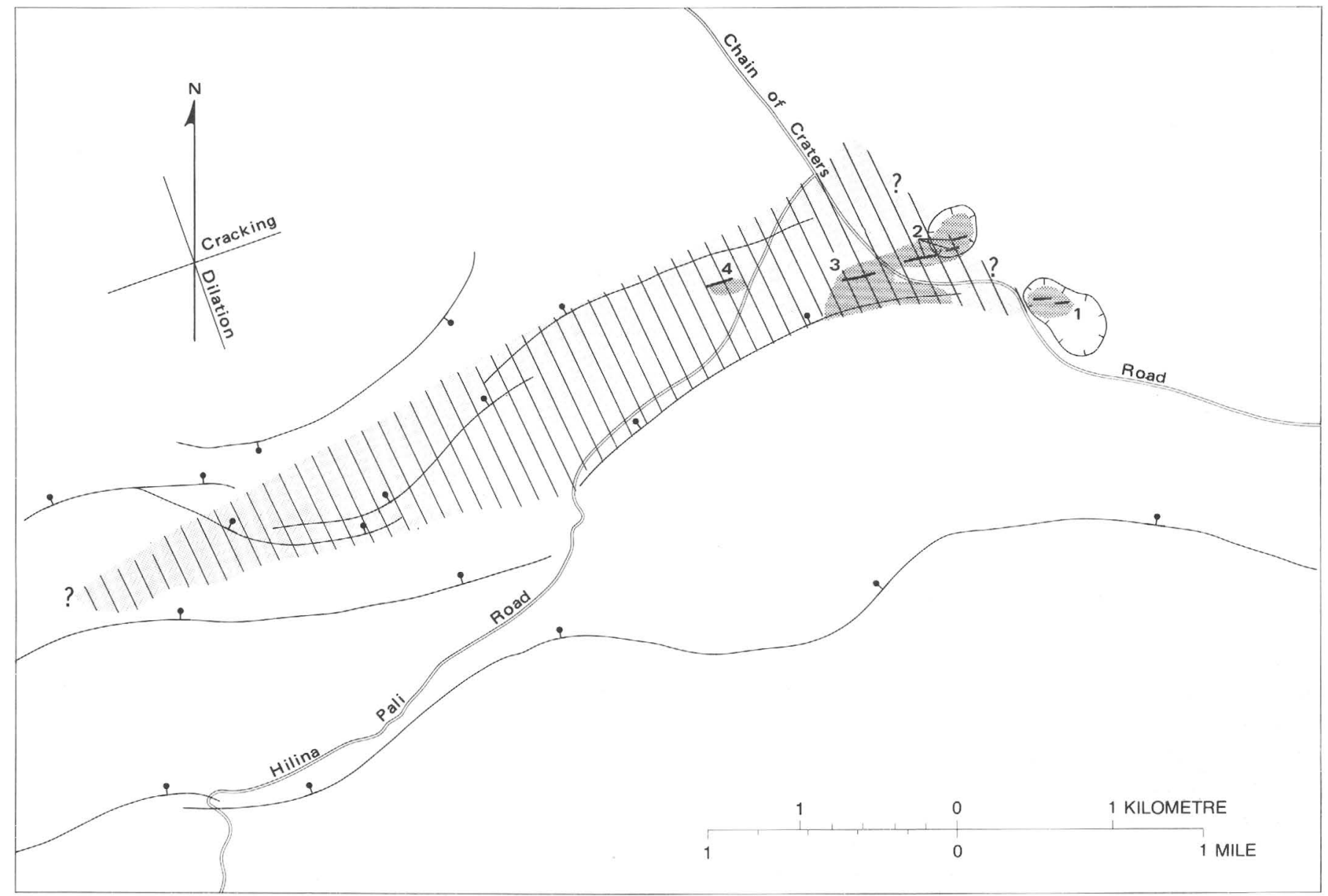

FIGURE 8-Eruptive fissures (numbered), lava flows (shaded), and approximate zone of ground cracking of the May 5, 1973, eruption (fine ruled pattern). Eruption began from fissure numbered 1 and moved successively uprift and into the Koae fault system to fissure numbered 4. Eruption-associated earthquakes migrated from northeast to southwest across the zone of ground cracking. 
Another method of estimating the oldest age of the present Koae faults is to assume that Koae dilation and the seaward displacement of the mobile south flank occur at the same rate. This is a corollary of the proposed origin of the fault system. D. A. Swanson, W. A. Duffield, and R. S. Fiske (unpub. data, 1973) have measured south-flank displacement of about 3-4 m in the past 70 years. Total Koae dilation of about 25 would require about 500 years to accumulate by extrapolation of the measured south-flank rate. Extrapolating a rate measured over such a short period of time, however, may well give spurious results.

A third means of estimating the age of the Koae comes from the spoken history passed from generation to generation by native Hawaiians. Ellis (1963) was told by natives that lava erupted from an area upslope from the Koae during the reign of a monarch who lived in about the middle of the 15 century. Barren pahoehoe below and in the west-central part of the Koae fault system may represent a flow from this eruption (H. A. Powers, written commun., 1974), suggesting a 500-year or younger age for development of the present Koae fault system.

The spread in the estimated ages is great, and all three methods of estimation are subject to large errors. Agreement between the geodetic and historical methods, however, suggests that the observed displacements in the Koae fault system may have taken place in the past 500 years. In any event, the growth of the Koae fault system almost certainly has been a long, continuing process, with evidence of earlier faulting now buried at increasingly deeper levels within the volcano. Similarly, the potential for continued fault development seems great.

Several lines of evidence suggest that the active part of the east rift has migrated southward through time (D. A. Swanson, W. A. Duffield, and R. S. Fiske, unpub. data, 1973), and so in general east-rift dikes are believed to be progressively younger from north to south. Presumably, then, fault zones in the Koae also are progressively younger to the south. There is no direct evidence of this arrangement in the Koae, but it is possible that the next zone of faulting may form south of the present south boundary of the fault system at some critical degree of southward east-rift migration.

\section{CONCLUSIONS}

The Koae fault system formed and continues to develop as part of the dilative growth process of Kilauea Volcano. Much evidence, especially the newly obtained geodetic and seismic measurements of D. A. Swanson, W. A. Duffield, and R. S. Fiske (unpub. data, 1973) and Koyanagi, Swanson, and Endo (1972), suggests that Koae faulting results from the forceful injection of dikes in the rift zones, as explained earlier. Comparison of the new data with the dilation direction of Koae faults suggests that the diking has caused this dilative growth throughout the entire history of the fault system. However, detailed spatial and temporal relations between diking and faulting have not yet been well demonstrated. The observations of Fiske and Koyanagi (1968) suggest that an east-rift magmatic event triggered faulting in the nearby Koae in December of 1965. The model predicts that the effects of dike-induced dilation originate at the site of diking and migrate outward, and so episodes of seismicity and faulting should be traceable from east to west in the Koae fault system for east-rift diking and in the opposite direction for southwest-rift activity. The model is undoubtedly oversimplified as stated and will be complicated by such effects as the threshold amount of dilative strain needed to cause Koae faulting. Nonetheless, a simple cause and effect relation between rift diking and Koae faulting is favored at this time.

For a thorough understanding of the relations between rift diking, Koae faulting, and a south-flank horizontal displacement, it is necessary to establish cause and effect for all processes. Moore and Krivoy (1964) believed that the east rift was a huge landslide fault and that diking was principally a passive process, with magma filling space left by renewed gravity-driven sliding on the rift. The precise leveling surveys of D. A. Swanson, W. A. Duffield, and R. S. Fiske (unpub. data, 1973), however, indicate large uplift of the south flank instead of subsidence expectable from landsliding. Furthermore, several observed episodes of east-rift dilation temporally associated with intrusion and eruption preceded episodes of south-flank displacement measured at points a few kilometres away, strongly suggesting a cause-and-effect relation between diking and south-flank displacement (D. A. Swanson, W. A. Duffield, and R. S. Fiske, unpub. data, 1973). Thus, current evidence favors forceful rift diking as the cause of both south-flank motion and Koae faulting.

\section{ADDED NOTE}

A brief eruption that bears directly on many of the statements made in this report occurred on May 5, 1973. The principal features of this activity are summarized here; a detailed description of the event will be written later by present members of the staff at the Hawaiian Volcano Observatory.

On the morning of May 5, lava was erupted successively uprift from four sets of fissures. Initial outbreak occurred in Pauahi Crater, followed by eruption in and adjacent to Hiiaka Crater, then in an area about $600 \mathrm{~m}$ west-southwest of Hiiaka Crater, and finally in the northeast part of the Koae fault system about $100 \mathrm{~m}$ west of Hilina Pali Road (fig. 8). The total volume of erupted lava was only about $10^{6} \mathrm{~m}^{3}$, some of which 
ponded against a north-facing Koae fault scarp. Structural effects were considerable and widespread.

All the eruptive fissures trend about N. $70^{\circ} \mathrm{E}$., the dominant east rift-Koae fault system direction: Accompanying ground cracking extends far beyond the areas of eruptive fissures and follows this same trend. A brief reconnaissance study by the writer in late May 1973 indicated abundant eruption-related ground cracking as far west as traverse line $A-A^{\prime}$ (pl. 1). New ground cracks are readily identifiable and show a total of $57 \mathrm{~cm}$ of horizontal dilation along line $A-A^{\prime}$ and about $150 \mathrm{~cm}$ along line $B-B^{\prime}$. Net dilation of the Koae resulting from the May cracking is somewhat less, however, because some preexisting open cracks were partly closed as new cracks opened. The directions of the newly opened cracks and dilation are consistent with the dominant directions indicated by the histograms of figure 3. Both right- and left-lateral en echelon arrangement of the new cracks is common.

Many of the new cracks cut directly across the south and central parts of the anomalous area of curvedconcentric cracks. (See section "Anomalous Areas.") These new cracks clearly resulted from the emplacement of a dike(s) in the east rift with slight impingement into adjacent parts of the Koae, and this known origin in conjunction with the crosscutting relation supports the earlier proposed idea of contrasting origins for cracks in the anomalous area versus those in other areas of the Koae.

Dike emplacement is indicated by several lines of evidence. The opening of long, narrow, parallel eruptive fissures suggests dike wedging. Furthermore, elongate ridges and complementary troughs of vertical ground displacement parallel the fissures, and the ground on either side was pushed and tilted away from the axial zone of uplift and cracking (Hawaiian Volcano Observatory, unpub. data, 1973). Possibly several dikes were injected into a zone as much as $600 \mathrm{~m}$ wide.

In general, eruption-related earthquakes spread westward across the Koae after initial concentration in the eruptive zone (Hawaiian Volcano Observatory, unpub. data 1973). This migration and the westward decrease in amount of new dilation as measured along the lines $A-A^{\prime}$ and $B-B^{\prime}$ indicate that the seismicity and cracking emanated from the eruptive zone and were almost certainly the result of a dike(s) that wedged its way to the surface there.
The May 5, 1973, eruption was remarkably similar to the typical Koae-forming event that was reconstructed from less direct evidence in the body of this report; it seems almost certain that the Koae fault system has developed from a multitude of similar events during the growth of Kilauea Volcano.

\section{REFERENCES CITED}

Cloos, Ernst, 1968, Experimental analysis of Gulf Coast fracture patterns: Am. Assoc. Petroleum Geologists Bull., v. 52, p. 420-444.

Duffield, W. A., and Nakamura, Kazuaki, 1973, A photogeologic method for determining the direction of horizontal dilation from patterns of en echelon fracturing: U.S. Geol. Survey Jour. Research, v. 1, no. 3., p. 283-287.

Ellis, William, 1963, Journal of William Ellis; narrative of a tour of Hawaii, or Owhyhee; with remarks on the history, traditions, manners, customs and language of the inhabitants of the Sandwich Islands: Honolulu, Advertiser Publishing Co., Ltd., 342 p.

Fiske, R. S., and Koyanagi, R. Y., 1968, The December 1965 eruption of Kilauea Volcano, Hawaii: U.S. Geol. Survey Prof. Paper 607, $21 \mathrm{p}$.

Hansen, W. R., 1965, Effects of the earthquake of March 27, 1964, at Anchorage, Alaska: U.S. Geol. Survey Prof. Paper 542-A, p. A1-A68.

Kinoshita, W. T., 1967, May 1963 earthquakes and deformation in the Koae fault zone, Kilauea Volcano, Hawaii, in Geological Survey research 1967: U.S. Geol. Survey Prof. Paper 575-C, p. C173-C176.

Koyanagi, R. Y., Swanson, D. A., and Endo, E. T., 1972, Distribution of earthquakes related to mobility of the south flank of Kilauea Volcano, Hawaii, in Geological Survey research 1972: U.S. Geol. Survey Prof. Paper 800-D, p. D89-D97.

Macdonald, G. A., 1957, Faults and monoclines on Kilauea Volcano, Hawaii: Geol. Soc. America Bull., v. 68, p. 269-271.

Moore, J. G., and Fiske, R. S., 1969, Volcanic substructure inferred from dredge samples and ocean-bottom photographs, Hawaii: Geol. Soc. America Bull., v. 80, p. 1191-1202.

Moore, J. G., and Krivoy, H. L., 1964, The 1962 flank eruption of Kilauea Volcano and structure of the east rift zone: Jour. Geophys. Research, v. 69, p. 2033-2041.

Powers, H. A., 1948, A chronology of the explosive eruptions of Kilauea: Pacific Sci., v. 2, no. 4, p. 278-292.

Rubin, M., and Suess, H. E., 1956, U.S. Geol. Survey radiocarbon dates III: Science, v. 123, no. 3194, p. 442-448.

Stearns, H. T., and Macdonald, G. A., 1946, Geology and ground water resources of the island of Hawaii: Hawaii Div. Hydrography Bull. 9, $363 \mathrm{p}$.

Swanson, D. A., 1973, Pahoehoe flows from the 1969-1971 Mauna Ulu eruption, Kilauea Volcano, Hawaii: Geol. Soc. America Bull., v. 84 , p. $615-626$.

Swanson, D. A., Duffield, W. A., and Okamura, R. T., 1971, Mobility of Kilauea's south flank related to rift intrusion [abs.].: Internat. Union Geodesy and Geophysics General Assembly, 15th, Moscow 1971, p. 29.

Walker, G. W., 1969, Geologic map of the Kau Desert quadrangle, Hawaii: U.S. Geol. Survey Geol. Quad. Map GQ-827, 1:24,000. 

